\title{
Danish Language
}

National Cancer Institute

\section{Source}

National Cancer Institute. Danish Language. NCI Thesaurus. Code C153894.

A North Germanic language spoken principally in Denmark and in the region of Southern Schleswig in northern Germany. 